\section{Berufsverbot: physics professor sacked}

SiR, Professor Jens Scheer, one of the leading critics of Germany's nuclear energy program, is to be forced to leave his life-long tenured position as professor of nuclear physics at the University of Bremen. The Administrative Court of the Free Hanse City of Bremen imposed this sentance of Berufsverbot (profession forbidden) in June after a disciplinary trial and retrial lasting two years. In its ruling the three-judge panel concluded: "As an appropriate disciplinary action for this offence only the heaviest one can be considered: expulsion from office".

The "offence"' appears in the Federal Constitutional Law for Civil Servants. It is only because the German civil service includes, inter alia, permanent university staff that professorScheer is bound by this law. This circumstance has important and unavoidable consequences especially for those who must teach and carry out objective research. The court stated:

"It is expected of a civil servant that he recognises and acknowledges the State and its constitution as a high postitive value worthwhile to defend actively; Federal Constitutional Law (Beschluss von 22,5, NJW 1975,1641 )"'. (This is applied to one's private life as well.) "According to this law (Art. 33 Abs. 466) a civil servant stands in public-legal relations of service and loyalty. That is why it is his duty to be loyal toward the State and the constitution (political loyalty-duty of the civil servant)."

The ideal of this law has been recurrently expressed in the last century of German History as a means to bring academics under the political scrutiny of the State authority. The present authorities have not changed history.

The nature of the trials of Professor Scheer is typical of the political trials going on in Germany today on a large scale. This latest Berufsverbot trial against him was based solely political principles and membership in the KPD (Communist Party of Germany) which is a legal party. The court noted that he "prominently", "publicly" and "actively" agreed with the principles of the party (i.e. he had recently stood as a local and parliamentary candidate and had sold the party newspaper). These were the only accusations used for the conviction and sentence. He was not allowed a complete defence.

Banning may come to those not quite bound by the golden chain of civil servant status, without court proceedings, after an investigation by the secret Federal Constitution Protection Police (BVSP) or because of accusations collected from paid informants of from fellow-teachers and pupils.

Over the past five years the authorities have brought at least seven prosecutions against Professor Scheer, one after the other. Since all these attempts failed, the authorities came eventually to rely on exclusively political accusations.

The present trials is in fact one of a series of Berufsverbot trials, where new charges have constantly been laid. The trials began before Professor Scheer became politically 'prominent'.

People who support Professor Scheer or who are terrified by the existence once again of these laws are asking the Senate of Bremen to overturn the court's ruling. These people include the Rector of the University, at least three-quarters of the professors, a similar majority of the University Staff Assembly and many students.

There is no doubt "that the West German authorities disregard individual rights and use improper methods in order to silence their critics". There is no doubt that the Civil Servants Law and its reflection in Bremen are tools to that end. And there is no doubt that neither truth nor democracy can proceed on the basis of loyalty, discipline and obedience. Yours faithfully,

UWE LAHL

University of Bremen

W THIEMANN

\section{Indian science}

SIR, "India: the struggle for useful science" by Anil Agarwal (23 August p 625) was objective - but gave very little account of the role of scientists in general. Though India boasts a large reservoir of talented and well-trained scientists, unemployment and underemployment among scientists are considerable. Many talented scientists fail to make any mark because of their inabilities to go along with the establishment. And when these scientists go abroad to prove their abilities, the establishment itself honours them. At least three Indian scientists have committed suicide out of sheer frustration in not being able to cope with the powers that be. Although everybody appreciates the role of science, no one has yet given any serious thought to the exact role and ambition of scientists in the research and developmental projects of which he is considered to be a part. Research institutions are mostly modelled on a bureaucratic pattern and, as correctly pointed out in the article, unless one turns into an administrator, a professional scientist is rarely honoured. Fortunately, there is no restriction as yet to free expression by scientists: hence this letter.

Yours faithfully,

Tocklai Experimental Station, Jorhat

B BANERJEE

\section{Humane farming}

SIR, Baker and Manwell (23 August, p630) strongly infer that I oppose "humane" treatment of farm animals by advocating intensive husbandry. This is incorrect. I am not an animal behaviourist, but I have supervised the rearing of farm animals in confinement, under experimental conditions, for many years. There are, broadly speaking, two approaches to humane treatment, pragmatic and anthropomorphic. The pragmatic approach says that inhumane treatment is counter-productive, because unhappy animals do not eat well, and hence do not thrive. Solitary confinement shows this Chickens search frantically for a companion. In one instance, two cows would not eat when separated, but started again when a window was cut in the partition. However, companionship may be de trop; egg production in hens is diminished by sexual harassment by male chauvinist roosters, which are therefore kept away, except in breeding flocks.

The floor space per animal allotted under confined conditions must be adjusted for maximum productivity, which is diminished by overcrowding. Composition and intake of food must be nutritionally optimal, drinking water always available, and ambient temperature such as to be compatible with good health. Dairy cows are notoriously sensitive, not to intensive husbandry, but to minor annoyances, which may make them refuse to let their milk down.

The anthropomorphic approach that decries crowding of farm animals is of dubious validity, in view of the fact tht human beings pay large sums to be jammed together at football games and in theatres. The most successful cocktail parties are tightly packed gatherings where the noise is deafening, and hotels in the United States display signs that warn against over-occupancy of meeting rooms. The chicken that has to roam in the out-of-doors probably would choose the protection of the hen-house against foxes, coyotes and Accipiter hawks.

Indeed, with rare exceptions, such as myself, wilderness conservationists dislike the solitude of the wilderness, for I have noted that most devotees of the Sierra Nevada seek out the few crowded areas, such as the John Muir Trail and the summit of Mount Whitney, leaving the choicer spots to darkness and to me.

Yours faithfully, THOMAS H JUKES

Berkeley, California

\section{Costs of toxicity testing}

SIR, Dr Conning in his letter of 2 August ( $p$ 354) draws attention to the problems facing the chemical industry worldwide, of society demanding greater assurance against the risks of error or of inadequate knowledge than it did in the past. One of the principal difficulties has been to anticipate the possible effects of a chemical on man and the environment before it was introduced into commerce, expecially in those cases where the effect may become apparent only after a long latent period.

In a Discussion Document published in June 1977, the Health and Safety Commission proposed to require by statutory regulation the formal prior study and reporting of the toxic properties of substances which were to be newly introduced. This was an attempt to establish a first order of priorities, since although - as Dr Conning rightly points out - even long experience of manufacture and use does not provide an infallible safeguard, at least by tackling urgently the 'new' substances we should not be adding to the existing list of 'don't knows'. HSE does not intend to produce guidelines on how to test chemicals, but merely to indicate what data would be needed as basic information for an evaluation of the properties of such substances.

It is common ground in this field that what we need are properly validated test procedures whereby chemicals may be screened effectively and at minimum cost in order to identify the hazards which they might present in manufacture and use. Such procedures must, however, be kept flexible in order not to dissipate resources in needless evaluation of effects which could be assessed from existing data either published or held in firms' archives. Yours faithfully,

Health and Safety Executive, London 